\title{
Handling of Brine Effluent of Desalination Plant through Producing Chemicals
}

\author{
Mai M Al Saadi*, Emad M Al Harrsi, Yaseen G Mushafri, Ammar Y Al Farsi and Greeb J Al Maharsi \\ Al Musanna College of Technology, Department of engineering, Faculty of mechanical, Oman
}

*Corresponding author: Mai Mubarak Al Saadi, Department of engineering, Faculty

Received Date: December 19, 2018

of mechanical, Oman.

Published Date: January 24, 2019

\begin{abstract}
Most of Gulf countries tend to operate Desalination plants in order to produce valid and fresh water for human being usage. Unfortunately, those plants discard huge tones of salts into sea and the concentrations of those salts are very high which can disturb the ecosystem in sea. In the addition these are mainly attributed to concentrate chemical discharges, which may impair coastal water quality and affect marine life. Brine is a solution of salt (usually sodium chloride) in water. Instead of dumping the brine into sea water as way of disposal. It is good to utilize the salt brine as raw material for producing different chemicals through electrolysis process. The process of electrolysis involves using an electric current and require a lot of electricity that is mainly produced by the electrical energy comes from a d.c. (direct current) battery or power pack supply. In the experiment power pack supply was used $(15 \mathrm{~V}, 0.48 \mathrm{~A}$ for 5 hours) in order to produce 1 liter of sodium hydroxide and 1 liter of hydrochloric acid. Moreover, there were other products such as sodium hypochlorite and chlorine gas which had been used to produce iron (I) chloride and Hydrogen gas was collected in balloon.
\end{abstract}

Keywords: Rejected salt brine; Electrolysis; d.c. (direct current); Chemical substances

\section{Introduction}
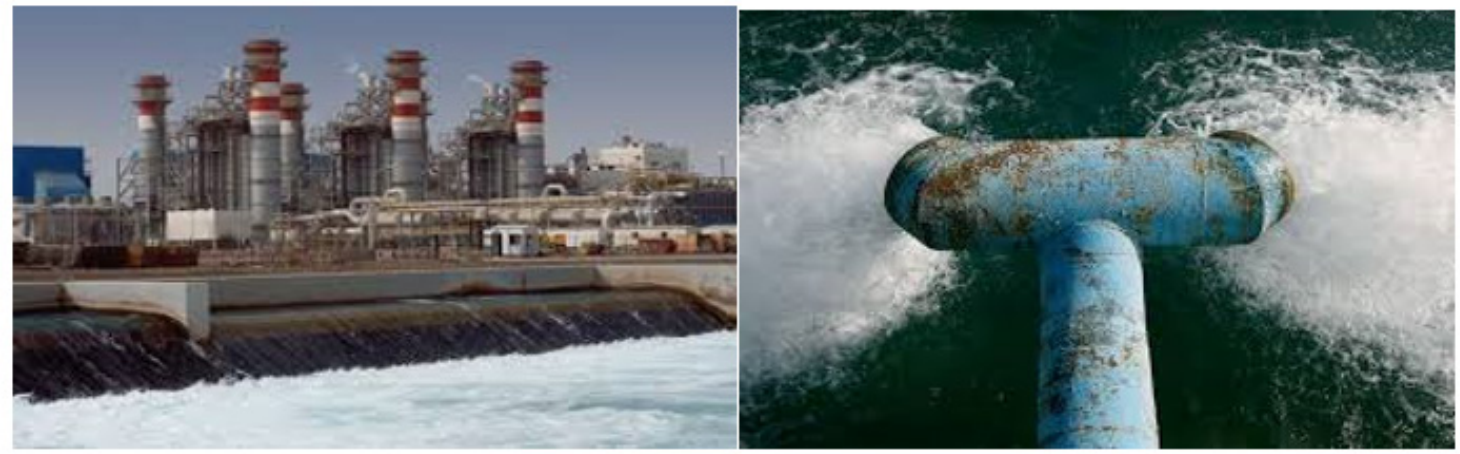

Figure 1: discharged rejected salt brine from desalination plants.

Desalination plants tended to treat sea water in order to have fresh water through desalination process which involves removing the salts like sodium chloride, Calcium and Magnesium chloride or sulphates and other salts from water, so they could supply the public and private sectors with their demands of water. Desalination plants over the world produce about 5000 million m3/year of water [1]. In addition, most of the desalination plants are combined with power plants for power production $[2,3]$ supply to the customers like what 
is happening with Sohar and Baraka desalination plants. However, there are more specific effects related to desalination plants such as impingement of marine organisms due to the intake of seawater and the greenhouse gases (GHG) emission due to a considerable energy demand of fossil fuel [4-7]. Furthermore, reject brine discharged to the sea has the ability to change the salinity, alkalinity and the temperature averages of the seawater and can cause change to marine environment. Desalination process has many byproducts like salt brine and the salinity of this solution is above $5 \%$ [8-11] (Figure 1).

Unfortunately, those plants had started to discard massive amounts or tones of salts into sea water and the concentrations of those salts became very high with passing time which could disturb the ecosystem in sea. In the addition these are mainly attributed to concentrate chemical discharges, which may impair coastal water quality and affect marine life.

Therefore, it advisable to monitor or observe the influence of discharged salt brine into sea water because water effluents typically cause a localized increase in sea water temperatures, which can directly affect the organisms in the discharge area. Increased temperature can affect water quality processes and result in lower dissolved oxygen concentrations. Furthermore, chlorination of the cooling water can introduce toxic substances into the water. Additionally, desalination plants can increase the salinity in the receiving water [2]. Instead of dumping the brine into sea water as way of disposal. It is good to utilize the salt brine as raw material for producing different chemicals through electrolysis process (Figure $2 \& 3$ ).

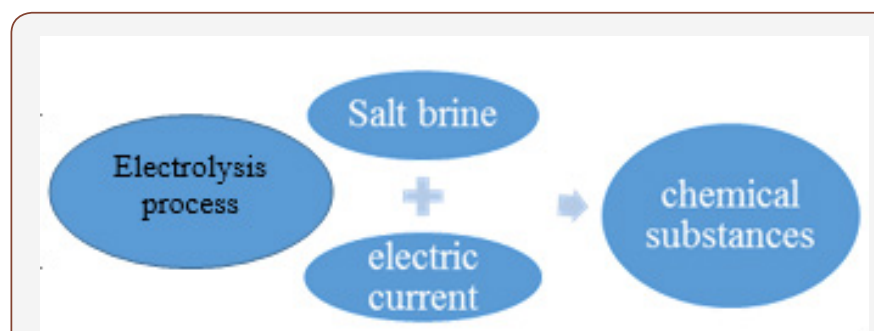

Figure 2: Electrolysis process

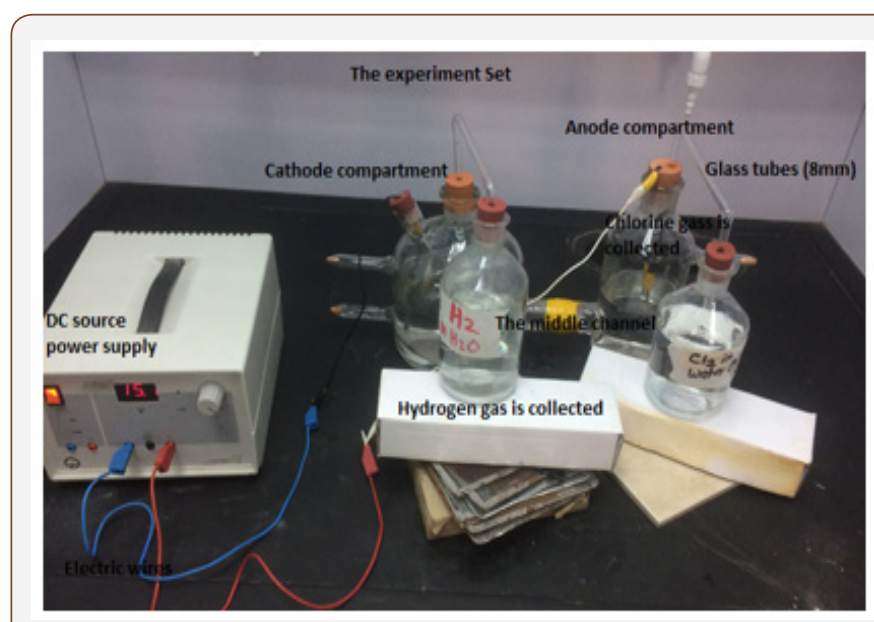

Figure 3: The set of the experiment of electrolysis process of salt brine.

\section{Project Significance}

As a whole, the project will be useful for Oman as country tend to widen its income sources and it can become more dependable in constructing their own industries and they can cover their needs from chemicals instead of importing from aboard. Moreover, this project could increase the job vacancies. However, the project can show how it is important to utilize discharge brine as raw material for manufacturing essential chemicals which have been used in different sectors and the chemicals which can be produced by this process such as chlorine gas, hydrogen gas and sodium hydroxide, bleach (sodium hypochlorite). Furthermore, it is good to implement new energy and substitute the conventional energy and that through using solar energy which will contribute in reducing air pollution and increase the goodness of air quality.

\section{Methodology}

10 liter of Salt brine sample was collected from Baraka desalination plant to be used in the experiment and 10 liters of Q-milli water was brought from higher college of technology.

Quantity measurement for the team and original products were handled in the laboratories of environment Science in higher college of Technology.

Quality measurement for the team an original product was conducted in Al-Musana college of Technology.

The industrial process which is used to produce those chemicals is called the electrolytic process (Chloralkali). Experimental process involves the electrolysis of aqueous sodium chloride (a brine) in a membrane cell.

Salt brine is rejected from desalination process and it is saturated solution of sodium chloride. Impurities need to remove from the solution by doing filtration process. Also resin tower can be used to chelate some metals. It is important to have purification for brine before being fed to the electrolytic cell. Note that the desalination plant water must be purified before entering the cell. Fill the anode chamber of the electrolytic cell with the brine. And the cathode chamber with pure water like Q-milli water or deionized water. Apply direct current (supply power) to the cell. Electric Current will scatter the solution into its ions which can move to opposite electrodes $\mathrm{H}+\mathrm{H}$ ions to cathode and $\mathrm{Cl}$ - ions to anode) and Only $\mathrm{Na}+$ ions can pass through ion exchange membrane to cathode chamber where pure water is available and then they react with $\mathrm{OH}$ - ions to form $\mathrm{NaOH}$ solution (Caustic Soda) and this soda can be collect separately in tank and its concentration about $30 \%$. Collect Hydrogen gas formed at cathode and chlorine gas at anode in separately. The chlorine and Hydrogen are washed, cooled to remove salt and further dehydrated before being delivered or liquefy.

\section{Results}

Rejected salt brine with what contains has been discharged in sea water with minor treatment in the form of dilution the concentration of brine solution. Recently, discharged salt brine led to increase the salinity in some of areas in al-batinah Sea water by 
comparing the salinity of sea water from Al-suwaiq, it was 4.254 ppt and about Baraka it reached to 5.672 ppt. That can be due to dumping back 8.508 ppt of salt brine into Baraka sea water.

The Table (1) shows the salinity of different samples which had been used in the experiment. It found that the salinity of sea water which was taken from Al-suwaiq sea water was around $4.254 \mathrm{ppt}$ and for Baraka sea water was around $5.672 \mathrm{ppt}$. Although both sea water of both Baraka and Al-Suwaiq wilaylats are located on Oman viken. But there is indication for increment in salinity in Baraka sea water due to dumping of salt brine which has salinity around 8.508 ppt.

Table 1: The chemical parameters and the salinity reading of water and salt brine sample.

\begin{tabular}{|c|c|c|c|c|}
\hline Salinity & TDS & Conductivity & $\mathbf{p H}$ & $\begin{array}{c}\text { Water and Salt } \\
\text { Brine Samples }\end{array}$ \\
\hline $2.836 \mathrm{ppt}$ & & $78.100 \mathrm{us}$ & 6.959 & Q-milli water \\
\hline $8.508 \mathrm{ppt}$ & $73.6 \mathrm{~g} / \mathrm{l}$ & $90.9 \mathrm{~ms}$ & 8.815 & salt brine \\
\hline $4.254 \mathrm{ppt}$ & & $54.700 \mathrm{~ms}$ & 7.972 & sea water SUW \\
\hline $5.672 \mathrm{ppt}$ & $51.9 \mathrm{~g} / \mathrm{l}$ & $52.300 \mathrm{~ms}$ & 7.98 & sea water BR \\
\hline
\end{tabular}

In the addition, many of coastal areas had been affected by salinity, especially Al-Batinah north where many lands became unsuitable for agricultures and planting therefore, it is important to have action regarding discharged salt brine from either Sohar or Baraka desalination plants.

With more trails, it could explain more about the situation of al-Batinah North Sea water and its salinity. The influence of Salinity on sea life, ground water and agricultural lands. Moreover, it could lead to increase the demand for electricity to operate desalination process.

In order to have high quality in the production of chemical substance $\mathrm{s}$ is required to implement very high amount of electricity because for ensuring massive disassociation of compounds in their ions. Therefore, it is good to construct the project in the area where both factors will be available, the salt brine as raw material and power can be supplied from power station production.

From above results (Tables 2\&3) which showed that there were similarities in our products and original products in quality parameters.

Table 2: The comparison between quantity measurements of the team products and original products.

\begin{tabular}{|c|c|c|c|c|}
\hline Reaction with base/Acid/cloth & & Indicator & & Product Type \\
\hline $\mathrm{NaHCO}_{3}$ & Litmus Paper & Methyl Orange & pH Indicator & Hydrochloric Acid (HCl) \\
\hline Releasing gas $\mathrm{CO}_{2}$ & Red & pink & colorless & Our product \\
\hline Releasing gas $\mathrm{CO}_{2}$ & Red & pink & colorless & Original product \\
\hline- & - & - & - & Sodium hydroxide $\mathrm{NaOH}$ \\
\hline Salt and water & blue & Light green & pink & Our product \\
\hline Salt and water & blue & Light green & pink & Original product \\
\hline- & - & - & - & Sodium hypochlorite $\mathrm{NaOCl}$ \\
\hline less & White & yellow & & Our project \\
\hline good & white & Dark yellow & light pink & Omani product \\
\hline strong & white & yellow & colorless & Saudi product \\
\hline good & white & Dark yellow & white & Eimarti product \\
\hline
\end{tabular}

Table 3: The comparison between quantity measurements of the team products and original products.

\begin{tabular}{|c|c|c|c|c|}
\hline Salinity & TDS & Conductivity & pH & Product Type \\
\hline- & - & - & Hydrochloric Acid (HCl) \\
\hline $16.1 \mathrm{ppt}$ & $61.05 \mathrm{~g} / \mathrm{l}$ & $27.91 \mathrm{~ms}$ & Our product \\
\hline- & $99.7 \mathrm{~g} / \mathrm{l}$ & $118.1 \mathrm{~ms}$ & Original product \\
\hline- & - & - & 0.597 & Sodium Hydroxide NaOH \\
\hline $12.4 \mathrm{ppt}$ & $18.38 \mathrm{~g} / \mathrm{l}$ & $21.92 \mathrm{~ms}$ & 11.978 & Our product \\
\hline- & $131.12 \mathrm{~g} / \mathrm{l}$ & $158.1 \mathrm{~ms}$ & 13.232 & Original product \\
\hline- & - & - & - & Sodium Hypochlorite NaOCl \\
\hline- & No reading & 43.23 & 12.384 & Our project \\
\hline $22.7 \mathrm{ppt}$ & - & $34.65 \mathrm{~ms}$ & 11.197 & Omani product \\
\hline $0.3 \mathrm{ppt}$ & - & $0.817 \mathrm{~ms}$ & 12.268 & Saudi product \\
\hline No reading & - & $38.01 \mathrm{~ms}$ & Eimarti product \\
\hline
\end{tabular}

The quantity parameter or chemical description for sample there were some difference in readings due to experimental issues. In first trial for the experiment there were lack in real materials which need to be in the experiment, so they had been substituted by simple and affective item till the real ones had been reached. Therefore, the second trail will be carried with new item. Definitely there will be major change the yield of our products. Also, it is required to have high electric current in order to get good quality of chemicals.

\section{Conclusion}

It is possible to produce the chemical substances from salt brine therefore we continue investigation and with more trials of the experiments. Definitely Sultanate of Oman will capable to cover 
their demand of those chemicals by itself instead of importing them from abroad.

\section{Acknowledgement}

-The Oman Power and Water Procurement Company (OPWP), Baraka Branch

-Al Musanna College of Technology, Department of engineering, Faculty of mechanical, Oman

-Higher College of Technology, Department of Science, Faculty of Applied Environment, Oman

\section{Conflict of Interest}

No Conflict of Interest.

\section{References}

1. Mohamed A Dawoud, Mohamed M Al Mulla (2012) Environmental Impacts of Seawater Desalination: Arabian Gulf Case Study International Journal of Environment and Sustainability 1(3): 22-37.

2. (2016) Manufacture and use of chemicals, Science.

3. (2016) Manufacturing chlorine using a diaphragm and a membrane cell.
4. (2016) Brine.

5. Van Der Steven JHG, Van Der Veen AJ, Waardenburg H, Hagedorn JA, Versteeg GF (1999) Application of the Maxwell-Stefan theory to the transport in ion-selective membranes used in the chlor-alkali, electrolysis process. Chemical Engineering Science 54(13-14): 25012511.

6. Doc Brown's Chemistry KS4 science-chemistry GCSE/IGCSE/AS Revision, (2016) electrolysis of sodium chloride solution.

7. Sushant Kumar, Surendra K Saxena (2013) Role of sodium hydroxide for hydrogen gas production and storage: Center for the Study of Matter at Extreme Conditions, College of Engineering and Computing, Florida International, University, Miami, Florida 33199, USA, pp. 452-463.

8. Christodoulos N, Christodoulou, George N, Karageorges, A REVIEW ON WATER ELECTROLYSIS, Centre for Renewable Energy Sources (CRES), Piker mi, Greece, Frederick Research Center (FRC), Nicosia, Cyprus.

9. Millet P, Andolfatto F, Durand R (1996) Design and performance of a solid polymer electrolyte water electrolyser. Int J Hydrogen Energy 21(2): 87-93.

10. M. Sc. Naresh Kumar Chavan from Gazipur, India, s t eady- s tat e and dynamic mode 1 ing of a chlor-alkal i cell with oxygen depolarized cathode, Mathematics/Computer Science and Mechanical Engineering, Clausthal University of Technology.

11. H Pütter (2001) Electrochemistry Forum Science, 1989. 